\section{Cesium-131 Brachytherapy Seeds for the Treatment of Sinonasal Carcinosarcoma: A Case Report and Literature Review}

\author{
Krupa R Patel ${ }^{1}$, Benjamin Talei ${ }^{2}$, Amy K Hsu ${ }^{2}$, Bhupesh \\ Parashar $^{3}$, Theresa Scognamiglio ${ }^{4}$ and David I Kutler ${ }^{2 *}$
}

${ }^{1}$ Weill Cornell Medical College, New York, USA

${ }^{2}$ Department of Otolaryngology-Head and Neck Surgery, New York Presbyterian Hospital/Weill Cornell Medical College, New York, USA

${ }^{3}$ Department of Radiation Oncology, New York Presbyterian Hospital/Weill Cornell Medical College, New York, USA

${ }^{4}$ Department of Surgical Pathology, New York Presbyterian Hospital/Weill Cornell Medical College, New York, USA

\begin{abstract}
\section{Background}

Radiation-induced tumors of the skull base pose a significant treatment challenge. Temporary Brachytherapy (BRT) with Cesium-131(Cs-131) seeds is a novel therapeutic technique that holds significant potential for the achievement of local tumor control in patients with limited therapeutic options.

Methods

We report a 70 year-old patient with a history of anaplastic oligoastrocytoma who presented with recurrent left-sided epistaxis Imaging and biopsy results revealed a high-grade carcinosarcoma of the paranasal sinuses and skull base. The Sinonasal Carcinosarcoma (SN-CS) was resected and the residual micro tumor was treated with Cs-131 BRT seeds attached to a vicryl mesh, which was removed 6 weeks later.

Results

Follow-up examination demonstrated no evidence of recurrence or metastasis for 9 months and the patient had an overall survival of 15 months after treatment with Cs-131 BRT.

\section{Conclusion}

Temporary BRT with Cs-131 seeds may play a pivotal role in achieving local tumor control and palliation in patients with aggressive skull base tumors who are precluded from receiving more extensive forms of radiotherapy.
\end{abstract}

*Corresponding author: David I Kutler, Department of Otolaryngology-Head and Neck Surgery, New York Presbyterian Hospital/Weill Cornell Medical College, NY 10065, USA, Tel: +1 6469624323; E-mail: dik2002@med.cornell.edu

Citation: Patel KR, Talei B, Hsu AK, Parashar B, Scognamiglio T, et al. (2017) Cesium-131 Brachytherapy Seeds for the Treatment of Sinonasal Carcinosarcoma: A Case Report and Literature Review. J Otolaryng Head Neck Surg 3: 007

Received: November 07, 2016; Accepted: March 14, 2017; Published: March 21, 2017
Keywords: Brachytherapy; Cesium-131; Cs-131; Sinonasal carcinosaroma; Skull base

\section{Introduction}

Carcinosarcoma tumors have been noted to occur in numerous anatomic sites including the uterus, breast, thyroid, and various subsites of the head and neck [1-5]. The salivary glands are the most common location of carcinosarcoma within the head and neck region [6]. The incidence of carcinosarcoma within the nasal cavity and paranasal sinuses is extremely rare and previous studies have consequently been limited to small case series and a recent systematic review [7-11].

Sinonasal Carcinosarcoma (SN-CS) tumors often present with nonspecific symptoms such as facial pain and unilateral nasal obstruction and have a reported 5-year disease-specific survival of $48.5 \%$ $[10,11]$. Because SN-CS can cause rapid and extensive local destruction, achieving prompt local control is of utmost importance in order to preserve function, obtain pain relief and thereby reduce patient morbidity. A recent systematic review of 86 cases of sinonasal teratocarcinoma reported radical surgical resection followed by radiation therapy to be the most commonly used therapeutic approach resulting in a $26 \%$ recurrence rate and $57 \%$ survival rate at approximately 4 years follow-up [11].

The use of External Beam Radiotherapy (EBRT), however, is often precluded, as in this patient, because a large proportion of SN-CS tumors are believed to reside within previously irradiated fields. The use of EBRT can in these circumstances result in significant toxicity to surrounding vital structures such as the brain, spinal cord, orbit, internal carotid arteries and optic nerves and may result in cerebrovascular accidents or rupture of the carotid artery [12]. Additionally, resection of skull base tumors is also often complicated by proximity or extension into critical structures resulting in suboptimal outcomes $[13,14]$. Cesium-131 (Cs-131) Brachytherapy (BRT) is an effective and highly conformal contemporary technique for administering further radiation in a previously irradiated field while limiting toxicity in the treatment of head and neck cancer [15-20].

Cesium-131 is a novel radioisotope that has only recently been reported in the treatment of recurrent head and neck cancers as an effective adjuvant therapeutic modality to surgical resection with low rates of acute toxicity [19]. We hypothesize that temporary Cs131 seed placement may hold significant therapeutic potential for the treatment of radiation-induced skull base tumors in the face of limited treatment options. Here, we report the first documented case of a primary skull base tumor treated with a temporary mesh containing Cs-131 BRT seeds after endoscopic resection and the resultant favorable outcome of local tumor control and no evidence of disease for 9-months post-treatment.

\section{Case Report}

\section{Patient demographics and clinical presentation}

A 70-year old male with poor cognitive function presented to an outside hospital in November 2010 with recurrent left-sided epistaxis. This patient had a history significant for anaplastic oligoastrocytoma 
diagnosed in 1994 for which he underwent craniotomy with resection and partial brain irradiation. In 2001, he experienced tumor recurrence and was subsequently treated with stereotactic radiotherapy and chemotherapy. The patient had a medical history further complicated by chronic ventriculoperitoneal shunt malfunction, seizure disorder; prostate cancer treated with anti-androgen therapy and a factor II mutation with recurrent deep vein thrombosis.

The patient underwent nasal endoscopy and excisional biopsy at an outside hospital in December 2010, which revealed a high-grade carcinosarcoma in the left ethmoid and sphenoid sinuses. Chemotherapy and EBRT were not administered due to the patient's overall poor health status and he was discharged on January $9^{\text {th }}, 2011$. In February 2011, the patient presented to New York Presbyterian Hospital/ Weill Cornell Medical Center with an admission diagnosis of aspiration pneumonia and upper gastrointestinal bleed. A brain MRI at this time for worsening cognitive function revealed a mass in the left paranasal sinuses (Figure 1). Following consultation with otolaryngology, the patient was taken to the operating room for a repeat biopsy, which confirmed the presence of a high-grade carcinosarcoma in the left ethmoid and sphenoid sinuses.
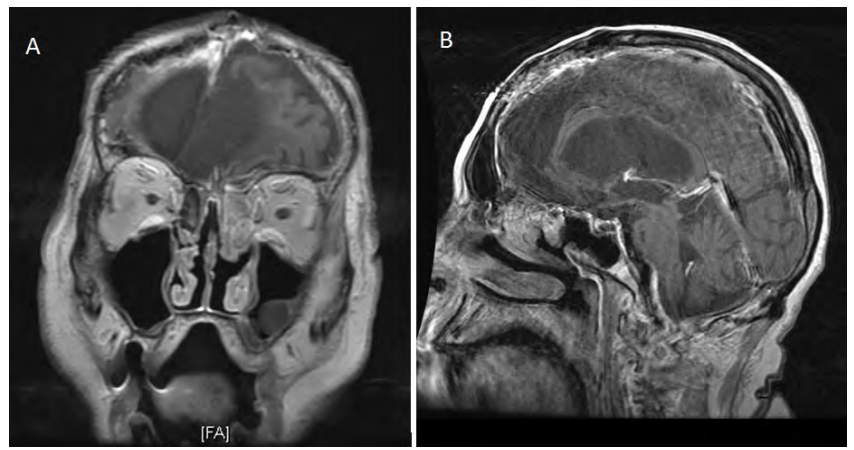

Figure 1: (a) Coronal and (b) Sagittal T1 with contrast MRI of spheno-ethmoidal carcinosarcoma.

\section{Tumor characteristics and therapeutic management}

The malignant epithelial component of the tumor specimen was positive with an immunohistochemical stain for p63 and negative for cytokeratin (AE1/AE3), chromogranin and synaptophysin; the malignant stromal component showed no heterologous differentiation and was negative for S100, myo-d1 and myogenin. This patient's case was discussed at a multidisciplinary tumor board meeting with otolaryngology and medical and radiation oncology, which yielded limited options. The patient's history of nearly toxic doses of irradiation for a prior brain neoplasm precluded him from receiving further EBRT and his poor overall functional status made him unsuitable for systemic chemotherapy. Given the location of the sinonasal malignancy proximal to the previously irradiated field and the timeline of the tumor being diagnosed 9 years after multiple brain radiotherapy treatments, it is most likely that the high-grade SN-CS was a long term sequela of his prior irradiation. He was taken back to the operating room on February 24, 2011 for a more definitive resection and placement of BRT seeds. A completion left endoscopic sinus surgery was performed with excision of a majority of the paranasal contents including the middle turbinate. Stereotactic navigation with Brain $\mathrm{Lab}^{\oplus}$ confirmed the removal of tissue bordering the skull base and orbit. The anterior and posterior ethmoid specimens demonstrated clear evidence of highgrade carcinosarcoma while all other sinus contents yielded chronically inflamed respiratory mucosa with or without bone (Figure 2).

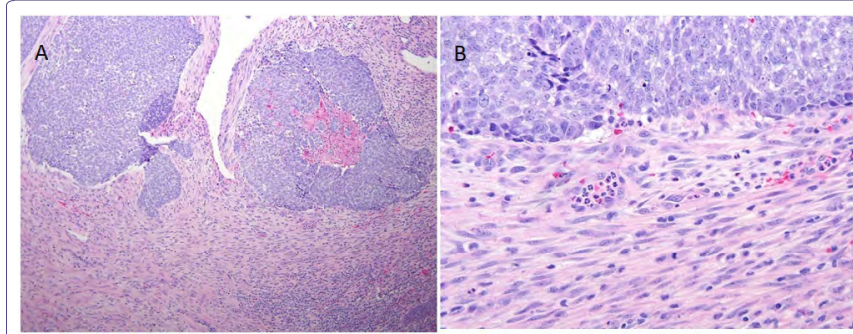

Figure 2: (a) 10x and (b) 40x representative views of the tumor specimen

The remaining micro tumor was treated with 20 Cs- 131 radiation seeds embedded $1 \mathrm{~cm}$ apart in suture strands attached to a vicryl mesh that was implanted utilizing stereotacic guidance and was secured to the tumor using surgical clips. The mesh was then further secured with a nasal tampon and absorbable packing, which were both removed at one week while leaving the mesh in place. The dose was determined based on a normogram developed by our radiation oncology department. The Cs-131 BRT seeds have a half-life of 9.7 days and an activity level of $1.57 \mathrm{U}(2.29 \mathrm{mCi})$ was used given the patient's history of multiple prior radiation treatments adjacent to the implanted site. The total expected radiation dose was 60 Gy to the surrounding tissues within $0.5 \mathrm{~cm}$ of the mesh. Proper placement of the mesh and BRT seeds was monitored by endoscopy and serial skull $\mathrm{x}$-rays (Figure 3 ). The implant was removed after 6 half lives resulting in a delivery of greater than $99 \%$ of the prescribed dose of 60 Gy (Figure 4). On April 4, 2011, the patient was taken back to the operating room for repeat sinonasal endoscopy and removal of the BRT seeds and vicryl mesh. There was no residual tumor noted at this time.

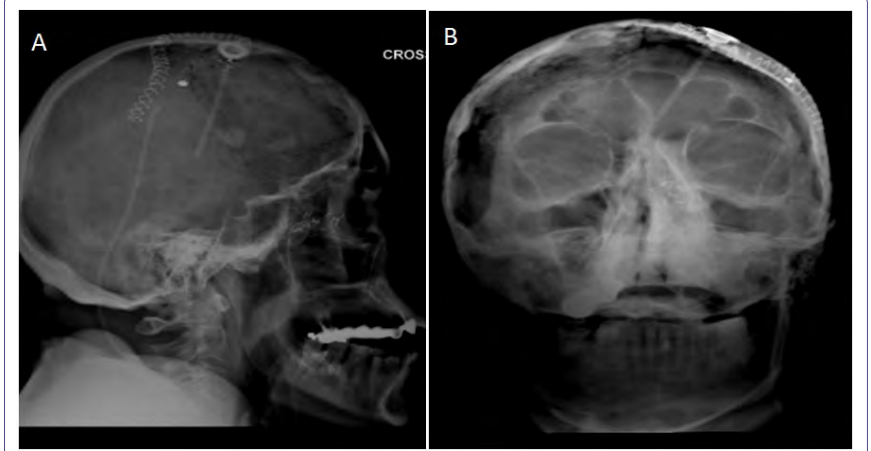

Figure 3: (a) Lateral and (b) Anteroposterior skull films after BRT seed placement.

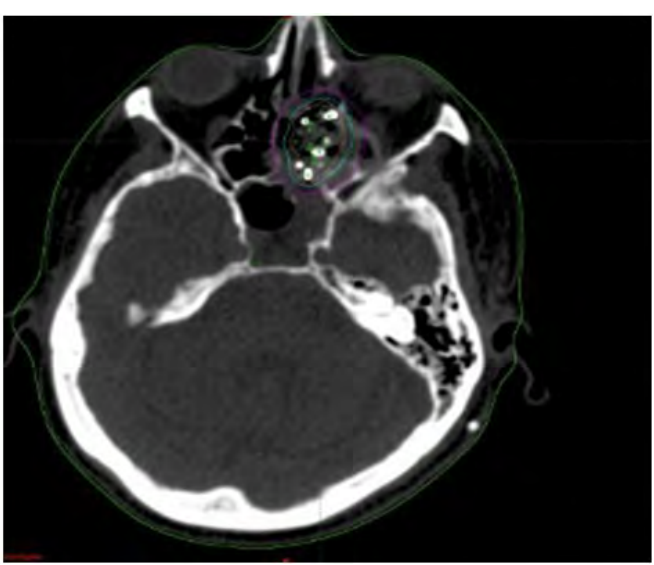

Figure 4: Radiation dosimetry diagram with green line representing the 60 Gy isodose line. 


\section{Patient outcome}

The patient continued to show no evidence of disease on November 17, 2011-roughly 9 months after therapy-when a brain MRI was performed for a work-up of progressively worsening mental status. The MRI displayed extra soft tissue and associated bone destruction in the region of the anterior left cavernous sinus and left orbital apex consistent with post-surgical changes. Additionally, the patient had no evidence of disease upon thorough endoscopic evaluation in the office. The patient was devoid of any symptoms related to the sinonasal tract at this time and a decision was made to withhold further treatment. He was subsequently re-admitted for worsening mental status and based on in-vitro data at that time, a 4-week trial of erlotinib 150 mg daily was initiated on February 10, 2012. As the patient progressed to an unresponsive state in the setting of persistent hydrocephalus, treatment was ceased and the patient was discharged home with hospice care in April 2012 and died approximately one month later.

\section{Literature Review and Discussion}

For the treatment of SN-CS, surgery and radiotherapy are the most frequently employed treatment modalities but no standard has been defined due to the relatively rare and heterogeneous nature of this neoplastic entity. Historically utilized most frequently in the treatment of gynecologic malignancies [21-23], BRT is now also an established therapeutic modality in the management of residual, recurrent and metastatic tumors of the head and neck region [15,16,24-29]. EBRT of the sinonasal tract and nasopharynx may result in both acute and late toxicities due to secondary radiation exposure to the optic chiasm, optic nerve, orbit and brainstem, especially in the setting of prior skull base irradiation. Additionally, the difficulty of obtaining clear margins and a satisfactory aesthetic outcome for sinonasal tract tumors in the setting of advanced and locally destructive disease has made BRT a common therapeutic modality utilized by head and neck surgeons.

A variety of different isotopes have been used for brachytherapy including cesium-131, gold-198, iodine-125, iridium-192, cobalt-60 and palladium-103 [30]. Several factors must be considered when choosing the type of source to utilize including the half-life, tumoricidal range, energy, and the ability to protect medical personnel and caregivers. In addition, a removable, temporary instead of a permanent source may be used in order to provide a lower risk of toxicity [30]. The radiation source can be implanted within the tumor mass (interstitial brachytherapy) or placed within a body cavity (intracavitary brachytherapy) and deliver radiation doses with high precision [18]. Utilization of BRT can thereby minimize the incidence of complications associated with radiation-induced adjacent tissue damage while treating and preventing progression of residual micro tumor. Although toxicities associated with brachytherapy are relatively low in comparison to conventional EBRT, potential side effects are not negligible. Toxicities in the head and neck region may include subcutaneous fibrosis, mucositis, ulceration, infections, fistula formation and necrosis $[25,31]$.

Methods for achieving local control within the nasal cavity, paranasal sinuses and skull base have varied widely. Combining surgical resection with radiotherapy is of utmost importance given the high recurrence rate of most tumors within these subsites. Furthermore, obtaining clear margins with paranasal space tumors is inherently difficult due to restricted bony access and proximity to vital structures despite advances in endoscopic and cranial base surgery. Teudt et al., recently described the outcomes of 35 patients with advanced stage sinonasal tract tumors treated with perioperative image-adapted brachytherapy with or without EBRT and chemotherapy and reported a $72 \%$ survival rate at 3 years [32]. Their study and others [20,3336] support the use of BRT to achieve local and regional control, to improve survival rates and to limit toxicity in patients with recurrent or advanced stage malignances of the nasopharynx and paranasal sinuses. Local control rates for nasopharyngeal carcinoma treated with surgery and intracavitary Ir-192 brachytherapy have been found to be similar to those of wide-field irradiation with lower complication rates [37]. In the management of neoplasms of the paranasal sinuses, the European Society for Therapeutic Radiology and Oncology (GEC-ESTRO) recommends BRT as sole therapy of residual disease following surgery with close margins, for superficial recurrences, for boost therapy following EBRT, and in combination with surgery for recurrent tumors [38].

For the management of skull base tumors such as those of the ethmoid and sphenoid sinuses, periorbital region, cribriform plate and maxillary antrum as well as the nasopharynx and nasal cavity, Intraoperative High Dose Rate BRT (IOHDR) maximizes local control and survival in patients with no previous radiation therapy, especially as a pre-EBRT boost [39]. The use of IOHDR in previously irradiated patients, however, resulted in poor outcomes [39]. Overall, the use of IOHDR with Ir-192 achieved $67 \%$ local control and $72 \%$ overall survival at 21 months for 29 patients diagnosed with recurrent or advanced skull base tumors [39]. Kumar et al., reported their experience using iodine-125 seed implantation as sole therapy for 5 recurrent, previously irradiated malignant tumors (clival chordoma, meningiomas, pituitary hemangiopericytomas and nasoparhyngeal and parotid carcinomas) with extension into the skull base. All cases reported by this group were treated with 1 or 2 permanent seed iodine-125 implants and achieved complete tumor resolution without any acute or chronic complications [40]. Other authors have also demonstrated the value of BRT in the management of advanced stage skull base tumors due to favorable palliative results and the preservation of visual acuity [41].

Several previous studies have thus reported on the success of brachytherapy for treatment of various histological subtypes of sinonasal and skull base tumors (Table 1). However, to our knowledge, this is the first paper to report the use of temporary Cs-131 BRT seeds for the treatment of a primary skull base tumor. We propose a novel therapeutic approach to patients with primary or recurrent skull base tumors, who are precluded from receiving EBRT or systemic chemotherapy. In this case report, we preferred the use of Cs-131 radiation seeds in a vicryl mesh in treating the SN-CS due to its conformity, high dose rate, short half-life ( 9.7 days) that ensures therapeutic radiation being delivered in a short time (in comparison, iodine- 125 has a half-life of 60 days) and limited exposure to staff and health care workers. Notably, the patient had no severe complications after BRT treatment.

The largest cohort of SN-CS patients studied $(n=15)$, for which the primary treatment modality was surgery with conventional radiotherapy, reported a disease-specific survival rate at 15 months of approximately $65 \%$ [10]. This patient had an overall survival time of 15 months post-treatment, which is relatively prolonged given the patient's extremely poor prognosis at presentation due to the aggressive nature of his tumor, his limited treatment options and his poor functional status. Overall, evidence from prior studies and this case report demonstrates that a high rate of local tumor control and improved survival, palliation and aesthetic outcomes can be achieved while minimizing toxicity and patient morbidity through meticulous 
Citation: Patel KR, Talei B, Hsu AK, Parashar B, Scognamiglio T, et al. (2017) Cesium-131 Brachytherapy Seeds for the Treatment of Sinonasal Carcinosarcoma: A Case Report and Literature Review. J Otolaryng Head Neck Surg 3: 007.

- Page 4 of 6 •

\begin{tabular}{|c|c|c|c|c|c|c|c|c|c|}
\hline Year & Journal & Reference & $\begin{array}{l}\text { No. } \\
\text { cases }\end{array}$ & Tumor site & Tumor histology & $\begin{array}{c}\text { Brachytherapy } \\
\text { type }\end{array}$ & $\begin{array}{l}\text { Median or } \\
\text { range of BRT } \\
\text { doses }\end{array}$ & Outcomes & $\begin{array}{c}\text { Mean } \\
\text { follow-up } \\
\text { (yrs) }\end{array}$ \\
\hline 1983 & Cancer & $\begin{array}{l}\text { Vikram et } \\
\text { al. [31] }\end{array}$ & 124 & $\mathrm{HN}$ & $\begin{array}{l}\text { Epidermod carcinoma }(n=111) \\
\text { salivary gland carcinoma }(n=10) \\
\text { thyroid carcinoma }(n=3)\end{array}$ & $\begin{array}{c}\text { Permanent } \\
\text { I-125 implants }\end{array}$ & 120 Gy & $\begin{array}{l}64 \% \text { local Control } \\
\text { rate at } 5 \mathrm{yrs} \\
27 \% \text { overall survival } \\
\text { rate at } 1 \mathrm{yr}\end{array}$ & 5 \\
\hline 1988 & Cancer & $\begin{array}{l}\text { Kumar et } \\
\text { al. [40] }\end{array}$ & 5 & Skull base & $\begin{array}{c}\text { Meningioma, } \\
\text { clivalchordoma, } \\
\text { pituitaryhemangiopericytoma, } \\
\text { nasopharyngeal carcinoma, } \\
\text { parotid carcinoma }(n=1)\end{array}$ & $\begin{array}{c}\text { Permanent } \\
\text { I-125 implants }\end{array}$ & 100 Gy & $\begin{array}{l}80 \% \text { local control } \\
\text { rate at } 3 \text { months, } \\
100 \% \text { overall surviv- } \\
\text { al rate at } 3 \text { yrs }\end{array}$ & 1.75 \\
\hline 1996 & $\begin{array}{l}\text { Radioth and } \\
\text { Onc }\end{array}$ & $\begin{array}{l}\text { Nag et al. } \\
\text { [39] }\end{array}$ & 29 & Skull base & $\begin{array}{c}\text { SCC }(n=21) \\
\text { undifferentiated }(n=3) \\
\text { chrondrosarcoma, esethioneu- } \\
\text { roblastoma, adenocarcionma, } \\
\text { adenoidcystic carcinoma, muco- } \\
\text { epidermoid carcinoma, basal cell } \\
\text { carcinoma }(n=1)\end{array}$ & $\begin{array}{l}\text { Intraoperative } \\
\text { Ir-192 HDR }\end{array}$ & 7.5-15 Gy & $\begin{array}{l}67 \% \text { local control } \\
\text { rate at } 21 \text { months, } \\
72 \% \text { overall survival } \\
\text { rate at } 21 \text { months }\end{array}$ & $\mathrm{N} / \mathrm{A}$ \\
\hline 2002 & $\begin{array}{l}\text { Laryngo- } \\
\text { scope }\end{array}$ & $\begin{array}{l}\text { Glatzel et } \\
\text { al. [25] }\end{array}$ & 90 & $\mathrm{HN}$ & N/A & $\begin{array}{l}\text { Interstitial or in- } \\
\text { tracavitarylr-192 } \\
\text { HDR }\end{array}$ & $17.5 \mathrm{~Gy}$ & $\begin{array}{l}46 \% \text { complete } \\
\text { remission rate, } \\
\text { median overall sur- } \\
\text { vival of } 7 \text { months }\end{array}$ & $\mathrm{N} / \mathrm{A}$ \\
\hline 2003 & $\begin{array}{l}\text { RadiothOn- } \\
\text { col }\end{array}$ & $\begin{array}{l}\text { Hall et al. } \\
{[37]}\end{array}$ & 18 & Nasopharynx & $\begin{array}{l}\text { Undifferentiated or SCC }(n=15) \\
\text { neuroendocrine carcinoma, } \\
\text { malignant melanoma, adenocarci- } \\
\text { noma }(n=1)\end{array}$ & $\begin{array}{l}\text { Intracavitary- } \\
\text { Ir-192 LDR \& } \\
\text { HDR }\end{array}$ & $30-63$ Gy & $\begin{array}{l}32 \% \text { local control } \\
\text { rate at } 5 \text { yrs, } \\
34 \% \text { overall survival } \\
\text { rate at } 5 \text { yrs }\end{array}$ & 5.7 \\
\hline 2005 & $\begin{array}{l}\text { Hong Kong } \\
\text { Med J }\end{array}$ & $\begin{array}{l}\text { Ngan et al. } \\
\quad[28]\end{array}$ & 13 & $\mathrm{HN}$ & $\begin{array}{l}\qquad \operatorname{SCC}(n=11) \\
\text { mucoepidermoid carcinoma }(n=1) \\
\text { alveolar soft-part sarcoma }(n=1)\end{array}$ & Interstitiallr-192 & $\begin{array}{l}70 \text { Gy (BRT } \\
\text { alone) } \\
35 \text { Gy (BRT + } \\
\text { EBRT) }\end{array}$ & $\begin{array}{l}75 \% \text { local control } \\
\text { rate at } 3 \text { years, } \\
89 \% \text { overall survival } \\
\text { rate at } 3 \text { years }\end{array}$ & 3.5 \\
\hline 2005 & $\begin{array}{l}\text { Strahlenth } \\
\text { and Onk }\end{array}$ & $\begin{array}{l}\text { Strege et } \\
\text { al. [41] }\end{array}$ & 18 & Skull base & $\begin{array}{l}\text { Paranasal sinus carcinoma }(n=10) \\
\text { sarcomas }(n=5) \\
\text { primitiveneuroectodermal tumor } \\
(n=2) \\
\text { parotid gland carcinoma }(n=1)\end{array}$ & $\begin{array}{l}\text { Interstitial Ir-192 } \\
\text { pulsed-dose- } \\
\text { rate/ high dose } \\
\text { rate afterloading }\end{array}$ & 10-30 Gy & $\begin{array}{l}\text { Median survival time } \\
\text { of } 16 \text { months }\end{array}$ & 1.2 \\
\hline 2007 & $\begin{array}{l}\text { Brachyther- } \\
\text { apy }\end{array}$ & $\begin{array}{l}\text { Narayana } \\
\text { et al. [26] }\end{array}$ & 30 & $\mathrm{HN}$ & $\mathrm{N} / \mathrm{A}$ & Interstitial HDR & $\begin{array}{l}40 \text { Gy (BRT } \\
\text { alone) } \\
34 \text { Gy (Postop- } \\
\text { erative BRT) } \\
20 \text { Gy (BRT + } \\
\text { EBRT) }\end{array}$ & $\begin{array}{l}63 \% \text { overall survival } \\
\text { rate at } 2 \text { yrs }\end{array}$ & 1 \\
\hline 2008 & $\begin{array}{c}\text { Radiat Oncol } \\
\text { Biol Phys }\end{array}$ & $\begin{array}{l}\text { Allen et al. } \\
{[35]}\end{array}$ & 9 & Nasal cavity & SCC (majority) and non-SCC & Interstitial Ir-192 & $65 \mathrm{~Gy}$ & $\begin{array}{l}86 \% \text { local control } \\
\text { rate at } 5 \text { yrs, } \\
82 \% \text { overall survival } \\
\text { rate at } 5 \text { yrs }\end{array}$ & 11 \\
\hline 2008 & $\begin{array}{l}\text { Laryngo- } \\
\text { scope }\end{array}$ & $\begin{array}{l}\text { Tselis et al/ } \\
{[36]}\end{array}$ & 2 & Nasal vault & Esthesioneuroblastoma & $\begin{array}{c}\text { Interstitial CT } \\
\text { guided HDR }\end{array}$ & $27 \mathrm{~Gy}$ & $\begin{array}{l}100 \% \text { overall surviv- } \\
\text { al at } 17 \text { months }\end{array}$ & 1.1 \\
\hline 2012 & $\begin{array}{l}\text { Head and } \\
\text { Neck }\end{array}$ & $\begin{array}{l}\text { Gaztanaga } \\
\text { et al. [27] }\end{array}$ & 97 & $\mathrm{HN}$ & scc & HDR & $\begin{array}{l}\text { 32-40 Gy (no } \\
\text { EBRT) } \\
\text { 16-24 Gy (BRT } \\
+ \text { EBRT) }\end{array}$ & $\begin{array}{l}52 \% \text { disease-free } \\
\text { survival at } 9 \mathrm{yrs}\end{array}$ & 4.3 \\
\hline 2013 & $\begin{array}{l}\text { J Contemp } \\
\text { Brachyther- } \\
\text { apy }\end{array}$ & $\begin{array}{l}\text { Scepanovic } \\
\text { et al. [34] }\end{array}$ & 1 & $\begin{array}{l}\text { Nasal cavity, } \\
\text { nasopharynx }\end{array}$ & Malignant melanoma & $\begin{array}{l}\text { Intracavitary } \\
\text { Ir-192 HDR }\end{array}$ & $72 \mathrm{~Gy}$ & $\begin{array}{l}\text { Regional progres- } \\
\text { sion of disease at } 6 \\
\text { months, } \\
\text { AWD at } 1 \mathrm{yr}\end{array}$ & 1 \\
\hline 2014 & $\begin{array}{l}\text { Brachyther- } \\
\text { apy }\end{array}$ & $\begin{array}{l}\text { Teudt et al. } \\
{[32]}\end{array}$ & 35 & $\begin{array}{l}\text { Sinonasal } \\
\text { tract }\end{array}$ & $\mathrm{N} / \mathrm{A}$ & $\begin{array}{l}\text { Perioperative } \\
\text { image-adapted } \\
\text { brachytherapry }\end{array}$ & $N / A$ & $\begin{array}{l}72 \% \text { overall survival } \\
\text { rate at } 3 \text { yrs }\end{array}$ & 2.3 \\
\hline 2015 & $\begin{array}{l}\text { Eur Arch } \\
\text { Otorhinolar- } \\
\text { yngol }\end{array}$ & $\begin{array}{l}\text { Kadah et } \\
\text { al. [18] }\end{array}$ & 20 & $\begin{array}{l}\text { Nasal cavity, } \\
\text { paranasal } \\
\text { sinuses, na- } \\
\text { sopharynx }\end{array}$ & $\begin{array}{c}\operatorname{SCC}(n=14) \\
\text { mixed tumors }(n=2) \\
\text { adenocarcinoma }(n=1) \\
\text { adenoid cystic carcinoma }(n=1) \\
\text { mucosal melanoma }(n=1) \\
\text { plasmocytoma }(n=1)\end{array}$ & $\begin{array}{l}\text { Intracavitary } \\
\text { Ir-192 HDR } \\
\text { afterloading }\end{array}$ & 10-20 Gy & $\begin{array}{l}57.3 \% \text { overall surviv- } \\
\text { al at } 2 \mathrm{yrs}\end{array}$ & 2 \\
\hline
\end{tabular}


Citation: Patel KR, Talei B, Hsu AK, Parashar B, Scognamiglio T, et al. (2017) Cesium-131 Brachytherapy Seeds for the Treatment of Sinonasal Carcinosarcoma: A Case Report and Literature Review. J Otolaryng Head Neck Surg 3: 007.

- Page 5 of $6 \cdot$

\begin{tabular}{|c|c|c|c|c|c|c|c|c|c|}
\hline 2015 & $\begin{array}{l}\text { Brachyther- } \\
\text { apy }\end{array}$ & $\begin{array}{l}\text { Tagliaferri } \\
\text { et al. [20] }\end{array}$ & 9 & $\begin{array}{l}\text { Sinonasal, } \\
\text { nasopharyn }\end{array}$ & $\mathrm{N} / \mathrm{A}$ & $\begin{array}{l}\text { Endoscopy } \\
\text { guided BRT }\end{array}$ & $30 \mathrm{~Gy}$ & $\begin{array}{l}\text { Median disease-free } \\
\text { survival of } 12 \\
\text { months, } \\
\text { median overall sur- } \\
\text { vival of } 23 \text { months }\end{array}$ & 1.6 \\
\hline
\end{tabular}

Table 1: Summary of reviewed relevant studies.

AWD, Alive With Disease; BCC, Basal Cell Carcinoma; HDR, High Dose Rate; HN, Head And Neck (Subsites Unspecified); IMBT, Intensity-Modulated Fractionated Interstitial Brachytherapy; LDR, Low Dose Rate; N/A, Information Not Available; SCC, Squamous Cell Carcinoma; UCNT, Undifferentiated Carcinoma of the Nasopharynx.

implementation of temporary Cs-131 BRT seeds in the management of recurrent, residual or advanced skull base disease. However, no randomized trials have been performed and there is a paucity of literature regarding clinical guidelines for the use of BRT for specific head and neck subsites, such as the sinonasal tract [38]. This literature review was limited by the lack of randomized controlled analyses and prospective studies regarding the use of BRT for sinonasal and skull base malignancies. Future studies may wish to focus on a more rigorous analysis of BRT protocols for sinonasal tumors and patients outcomes.

\section{Conclusion}

Endoscopic surgical resection and subsequent implantation of a temporary mesh with Cs-131 BRT seeds resulted in a 9-month disease-free interval in a patient with SN-CS presenting with an otherwise poor prognosis. In the management of patients with aggressive skull base tumors, careful implementation of temporary BRT seeds has the potential to achieve local and regional tumor control and palliation in patients who are precluded from receiving more extensive forms of radiotherapy and chemotherapy.

\section{References}

1. Kedzia W, Pruski D, Iwaniec K, Przybylski M, Friebe Z, et al. (2012) Carcinosarcoma (malignant mixed mesodermal tumor) of the uterus: clinicoimmunohistochemical and histogenetic characteristics. Folia Histochem Cytobiol 50: $513-518$

2. Mele M, Jensen LL, Vahl P, Funder JA (2015) Breast carcinosarcoma: clinical and pathological features. Breast Dis 35: 211-215.

3. Agrawal M, Uppin SG, Challa S, Prayaga AK (2013) Carcinosarcoma thyroid: An unusual morphology with a review of the literature. South Asian J Cancer 2: 226.

4. Shindo ML, Stanley RB Jr, Kiyabu MT (1990) Carcinosarcoma of the nasal cavity and paranasal sinuses. Head Neck 12: 516-519.

5. Galli J, Parrilla C, Corina L, Ricci R, Paludetti G (2005) Carcinosarcoma of the submandibular salivary gland: clinical case and review of the literature. $J$ Otolaryngol 34: 66-69.

6. Stephen J, Batsakis JG, Luna MA, von der Heyden U, Byers RM (1986) True malignant mixed tumors (carcinosarcoma) of salivary glands. Oral Surg Oral Med Oral Pathol 61: 597-602.

7. Heffner DK, Hyams VJ (1984) Teratocarcinosarcoma (malignant teratoma?) of the nasal cavity and paranasal sinuses A clinicopathologic study of 20 cases. Cancer 53: 2140-2154.

8. Pai SA, Naresh KN, Masih K, Ramarao C, Borges AM (1998) Teratocarcinosarcoma of the paranasal sinuses: a clinicopathologic and immunohistochemical study. Hum Pathol 29: 718-722.

9. Budrukkar A, Agarwal JP, Kane Set, Siddha M, Laskar SG, et al. (2010) Management and clinical outcome of sinonasal teratocarcinosarcoma: single institution experience. J Laryngol Otol 124: 739-743.

10. Patel TD, Vazquez A, Plitt MA, Baredes S, Eloy JA (2015) A case-control analysis of survival outcomes in sinonasal carcinosarcoma. Am J Otolaryngol 36: $200-204$
11. Misra P, Husain Q, Svider PF, Sanghvi S, Liu JK, et al. (2014) Management of sinonasal teratocarcinosarcoma: a systematic review. Am J Otolaryngol 35: 5-11.

12. Parsons JT, Mendenhall WM, Stringer SP, Cassisi NJ, Million RR (1995) Salvage surgery following radiation failure in squamous cell carcinoma of the supraglottic larynx. Int J Radiat Oncol Biol Phys 32: 605-609.

13. Agra IM, Carvalho AL, Pontes E, Campos OD, Ulbrich FS, et al. (2003) Postoperative complications after en bloc salvage surgery for head and neck cancer. Arch Otolaryngol Head Neck Surg 129: 1317-1321.

14. Goodwin WJ Jr (2000) Salvage surgery for patients with recurrent squamous cell carcinoma of the upper aerodigestive tract: when do the ends justify the means? Laryngoscope 110: 1-18.

15. Lapeyre M, Coche-Dequeant B, Moreira JF, Le Bourhis J, Peiffert D (2013) [Brachytherapy for head and neck cancers]. Cancer Radiother 17: 130-135.

16. Strnad V, Lotter M, Kreppner S, Fietkau R (2013) Interstitial pulsed-dose-rate brachytherapy for head and neck cancer--Single-institution long-term results of 385 patients. Brachytherapy 12: 521-527.

17. Bussu F, Tagliaferri L, Mattiucci Get, Parrilla C, Dinapoli N, et al. (2016) Comparison of interstitial brachytherapy and surgery as primary treatments for nasal vestibule carcinomas. Laryngoscope 126: 367-371.

18. Kadah BA, Niewald M, Papaspyrou G, Dzierma Y, Schneider M, et al. (2015) Customized individual applicators for endocavitary brachytherapy in patients with cancers of the nasal cavity, sinonasal region and nasopharynx. European Archives of Oto-Rhino-Laryngology 273: 1543-1547.

19. Pham A, Arora S, Wernicke Ge A, Kutler DI, Cohen M, et al. Cesium-131 brachytherapy in high risk and recurrent head and neck cancers: first report of long-term outcomes. J Contemp Brachytherapy 7: 445-452.

20. Tagliaferri L, Bussu F, Rigante M, Gambacorta MA, Autorino R, et al. Endoscopy-guided brachytherapy for sinonasal and nasopharyngeal recurrences. Brachytherapy 14: 419-425.

21. Mahdi H, Rose PG, Elshaikh MA, Munkarah A, Isrow D, et al. (2015) Adjuvant vaginal brachytherapy decreases the risk of vaginal recurrence in patients with stage I non-invasive uterine papillary serous carcinoma. A multi-institutional study. Gynecol Oncol 136: 529-533.

22. Nakano T, Kato S, Ohno T, Tsujii H, Sato S, et al. (2005) Long-term results of high-dose rate intracavitary brachytherapy for squamous cell carcinoma of the uterine cervix. Cancer 103: 92-101.

23. Cravello L, Gonzague-Casabianca L, Roger V, d'Ercole C, Smart C, et al (1999) Brachytherapy and vaginal hysterectomy for low-stage uterine cervix carcinoma. Gynecol Oncol 72: 102-106.

24. Tselis N, Ratka M, Vogt HG, Kolotas C, Baghi M, et al. (2011) Hypofractionated accelerated CT-guided interstitial 192Ir-HDR-Brachytherapy as re-irradiation in inoperable recurrent cervical lymphadenopathy from head and neck cancer. Radiotherapy and oncology 98: 57-62.

25. Glatzel M, Büntzel J, Schröder D, Küttner K, Fröhlich D (2002) High-doserate brachytherapy in the treatment of recurrent and residual head and neck cancer. Laryngoscope 112: 1366-1371.

26. Narayana A, Cohen GN, Zaider M, Chan K, Lee N, et al. (2007) High-doserate interstitial brachytherapy in recurrent and previously irradiated head and neck cancers--preliminary results. Brachytherapy 6: 157-163. 
27. Gaztañaga M, Pagola M, Cambeiro M, Rodriguez Ruiz ME, Aristu J, et al. (2012) Comparison of limited-volume perioperative high-dose-rate brachytherapy and wide-field external irradiation in resected head and neck cancer. Head Neck 34: 1081-1088.

28. Ngan RK, Wong RK, Tang FN, Tang DL (2005) Curative radiotherapy for early cancers of the lip, buccal mucosa, and nose--a simple interstitial brachytherapy technique employing angiocatheters as carriers for Iridium-192 wire implants. Hong Kong Med J 11:351-359.

29. Nutting C, Horlock N, A'Hern R, Searle A, Henk JM, et al. (2006) Manually after-loaded 192Ir low-dose rate brachytherapy after subtotal excision and flap reconstruction of recurrent cervical lymphadenopathy from head and neck cancer. Radiother Oncol 80: 39-42.

30. Suntharalingam N, Podgorsak EB, Tolli H (2005) Brachytherapy: Physical and Clinical Aspects. Podgorsak EB (ed.). Radiation Oncology Physics: A Handbook for Teachers and Students, International Atomic Energy Agency (IAEA), Vienna, Austria.

31. Vikram B, Hilaris BS, Anderson L, Strong EW (1983) Permanent lodine-125 implants in head and neck cancer. Cancer 51: 1310-1314.

32. Teudt IU, Meyer JE, Ritter M, Wollenberg B, Kolb T, et al. (2014) Perioperative image-adapted brachytherapy for the treatment of paranasal sinus and nasal cavity malignancies. Brachytherapy 13: 178-186.

33. Lipman D, Verhoef LC, Takes RP, Kaanders JH, Janssens GO (2015) Outcome and toxicity profile after brachytherapy for squamous cell carcinoma of the nasal vestibule. Head \& neck 37: 1297-1303.

34. Scepanovic D, Paluga M, Rybnikarova M, Pobijakova M, Masarykova A, et al. (2013) Brachytherapy as a treatment for malignant melanoma of the nasa cavity and nasopharynx - case report. J Contemp Brachytherapy 5: 157-163.
35. Allen MW, Schwartz DL, Rana V, Adapala P, Morrison WH, et al. (2009) Long-term radiotherapy outcomes for nasal cavity and septal cancers. Int J Radiat Oncol Biol Phys 71: 401-406.

36. Tselis N, Heyd R, Baghi M, Zamboglou N (2008) Interstitial high-dose-ratebrachytherapy in advanced esthesioneuroblastoma. Laryngoscope 118 2006-2010.

37. Hall CE, Harris R, A'Hern R, Archer DJ, Rhys-Evans P, et al. (2003) Le Fort I osteotomy and low-dose rate Ir192 brachytherapy for treatment of recurrent nasopharyngeal tumours. Radiother Oncol 66: 41-48.

38. Mazeron JJ, Ardiet JM, Haie-Méder C, Kovács G, Levendag P, et al. (2009) GEC-ESTRO recommendations for brachytherapy for head and neck squamous cell carcinomas. Radiother Oncol 91: 150-156.

39. Nag S, Schuller D, Pak V, Young D, Grecula J, et al. (1996) Pilot study of intraoperative high dose rate brachytherapy for head and neck cancer. Radiother Oncol 41: 125-130.

40. Kumar PP, Good RR, Leibrock LG, Mawk JR, Yonkers AJ, et al. (1998) High activity iodine 125 endocurietherapy for recurrent skull base tumors. Cancer 61: 1518-1527.

41. Strege RJ, Kovács G, Maune S, Holland D, Niehoff P, et al. (2005) Feasibility of Combined Operation and Perioperative Intensity-Modulated Brachytherapy of Advanced/Recurrent Malignancies Involving the Skull Base. Strahlenther Onkol 181: 97-107. 